\title{
Social Changes in the Post-Tsunami Banda Aceh City
}

\author{
Ismail $^{1}$, Salahuddin, $\mathbf{S}^{\mathbf{1}}$. Amirulkamar ${ }^{1}$ \\ ${ }^{I}$ Iskandarmuda of University, Aceh, Indonesia \\ sal_salahuddin@yahoo.co.id
}

\begin{abstract}
Post-Tsunami Aceh has a significant impact on the people of Banda City, especially during and after rehabilitation and reconstruction has caused dependence and various kinds of social problems as a problem that arises so that social change occurs. The social change of the people of Banda Aceh City does not all lead to positive things, but also the changes refer to the negative direction. The social change in question is a change in the social value of the people of Banda Aceh due to assistance (cash for work) given to the community during the rehabilitation and reconstruction so that social changes occur. This study aims to examine and describe why social change occurred in the people of Banda Aceh after the tsunami using a qualitative approach. Data obtained through observation and interviews with various speakers. Determination of informants was done by purposive sampling with consideration of the informants were part of the community of Banda Aceh and people who survived the tsunami disaster. To analyze the research researchers used the theory of social change. The results showed that after the tsunami there had been a social change in the people of Banda Aceh City, there were positive changes, some were negative. Positive changes in the community feel that many help so that they can meet their needs in the short term, while the larger negative impacts, especially regarding social values such as the level of community participation in Banda Aceh in the construction of village development decrease, are evident from the fading of mutual cooperation inherent in community members and weak social responsibility resulting from dependence and individualistic attitudes.
\end{abstract}

Keywords : social change; society; Banda Aceh

\section{Introduction}

The people of Banda Aceh changed their attitudes, habits and daily habits after the tsunami struck Aceh in December 2004. The people of Banda Aceh are known to be independent and creative and transformed into an inspired society that also requires assistance provided by outside parties according to their needs depending on assistance, was given by various NGOs. This seems interesting which raises various kinds of social problems in community life. It also brings people to change towards more selfish ones and vice versa in taking community activities such as mutual cooperation because they do not get paid by NGOs from outside. Changes in value cause social values that cause social change.

This social change is ironically negative but also positive. Negative social changes such as doing cooperation and everything starting to be calculated with money, changing social values such as the assessment of the people of Banda Aceh in community social activities at the village level increases the risk of shifting cooperation relationships with mutual cooperation and also contains a sense of responsibility social as well as prioritizing passive and individualistic attitudes. Then the depletion of social capital requested by the people of Banda Aceh City, even though previously it was known as a community that carried out various community activities by putting forward the same weight lightly carried on the same hand. But after the tsunami there was a change that was quite drastic until there were changes in various things in social life.

However, after the tsunami, the people of Banda Aceh did not end up in sorrow because they cared a lot about the material and socially. Good intentions and great efforts given by 
various parties to the people of Banda Aceh on the one hand as a gift but on the other hand related to the community on the other side in this case various stakeholders involved in carrying out interactions and transactions with the people of Banda Aceh after the tsunami. Thus there are various social changes in social life. The empirical data on the location of the study shows that this change can also be seen from the more open pattern of community style about anti-social debates and mutual counting of participation must produce good opinions that contain financial and material.

In connection with the description above, this study wants to analyze the main causes of changes made by the people of Banda Aceh City after the tsunami.

\section{Literature Review}

\subsection{Theory of Social Change}

The social changes that have taken place in the city of Banda Aceh can be identified by comparing the conditions of the community before and after the tsunami. The process of change in society occurs because humans are creatures that think and work. Social change is a change in the interaction relationship between people, organizations or communities, it can involve social structures, values and norms and roles. According to Sukowati (2011: 3) Social Change is "the process by which changes in the structure and function of a social system. These changes occur as a result of the inclusion of renewal ideas adopted by members of the relevant social system". Whereas Moore in Sukowati (2011: 7) "social change is a part of cultural change. Changes in culture include all parts which include art, science, technology, philosophy and so on ".

Soekanto (2012) social change refers to changes in social aspects, community governance, and group behavior patterns. One example of social change is the increasing number of formal community institutions. For example various organizations ranging from government organizations, to social gathering organizations, are now becoming more formal, with a more rational pattern of relations. This is different from social organizations in the past, which are more informal by using emotional relationships. Davis in Soekanto (2012) defines social change as a change that occurs in the function and structure of society.

Social change is said to be peer change in social relationships or as a change in the equilibrium of social relations. According to Selo Soemardjan, Social Change is a change that occurs in social institutions within a society that affect the social system, including values, attitudes, and behavior patterns among groups in society. According to him, between social change and cultural change has one aspect in common, both of which have to do with an acceptance of a new way or an improvement in the way people fulfill their needs.

Basically, social change occurs because community members at any given time feel dissatisfied with their old life. Norman norms and institutions of social institutions or old means of livelihood are considered to be inadequate to meet new life needs. The trigger factor for the occurrence of social change can come from within (internal) or from outside (external) society. There is no single society that can stand alone without interacting with other parties in the world. It is impossible if there is a claim that a nation is not involved in the world arena but exists. This phenomenon cannot be separated from the flow of movement of influence from a nation to another nation which is often identified with the term 'globalization'.

The theory that will explain relating to social change is the theory of evolution. Evolutionary changes are imagined as "unilinear patterns" following a single pattern or 
trajectory. The difference between various parts of society or between cultures in human society as a whole is thought to be caused by different steps in the evolutionary process in various parts of the world, some of which are slow and some are faster. A backward society is certainly very late in the process, but without being neglected it will move, through the same path, to follow a more developed society, especially the most mature Western society.

The factors that influence the course of a change process according to Soekanto (2012) include: contact with other cultures, advanced formal education systems, respect for the work of others and desires to progress, tolerance for deviant actions, open systems layers of society, heterogeneous populations, community dissatisfaction with certain areas of life, as well as future orientation and values that humans must always take to improve themselves.

Social change in society can involve all changes in social institutions, their social systems both from within and from outside. The causes that come from within the community itself include: Increasing or decreasing population, new discoveries, conflicts in society, and the occurrence of rebellions or revolutions within the body of the society itself. While the causes that come from outside the community include: Causes that originate from the physical environment that exists around humans, war with other countries, and the influence of other people's cultures.

The processes of social change that occur in the community can be in the form of community adjustment to change, channels of change that are passed by a process of change, disorganization (disintegration) and reorganization (reintegration). Organization is the articulation of parts which are part of roundness that is in accordance with their respective functions. Disorganization is the process of waning norms and values in society, due to changes that occur in community institutions.

The aspects of social change can be discussed in two dimensions. First, the aspects associated with cultural layers consist of material aspects, norms and aspects of values. Second, aspects related to the fields of social life of the community, which in this learning activity are expressed in the fields of economic life, the field of family life, and community institutions. Material cultural aspects are aspects that are material and can be touched or seen in real terms, such as clothing, work tools, and so on. Because of its material nature, this aspect of culture is relatively fast changing. The aspects of norms concern in the rules or social norms that regulate the interaction between all citizens. This aspect is relatively slower to change compared to the material aspects of culture. Other aspects are cultural values (values), which are related to noble values that are the views or philosophy of life of the community. These values underlie social norms which become the rules of interaction between citizens.

\subsection{Society Theories}

Society is a collection of people who live together for quite a long time. So it's not just a crowd or a crowd in a moment, like a crowd of terminals, markets or on a soccer field. In the long time together, social interaction occurred. Furthermore, the people who form the community must have awareness that they are a unity. Community is a system of living together, where they create values, norms, and culture for their lives.

Gillin in Sukidin et al (2003: 102) defines society as "the largest human group, which has the same habits, traditions, attitudes, and feelings of unity". From the description, the elements of society consist of:

1. Collection of people. 
2. It has been formed for a long time.

3. Already has its own social system and structure.

4. Having beliefs (values), attitudes, and behaviors that are shared.

5. There is continuity and self-defense.

6. Having culture.

According to Simmel in Soekanto (2012) society will emerge through "the process of reciprocal interaction where individuals interact and influence each other. This approach seeks a balance between the nominalist views which suggest that social reality is independent of the individuals who make up ". Whereas according to Suparlan in Soekanto (2012) society is "a combination of groups of individuals formed based on a particular social order. In social literature three forms of society are known, namely: 1) homogeneous society; 2) plural societies; 3) and heterogeneous societies. The community that became the discussion in this study was the heterogeneous community of Banda Aceh City.

\section{Research Method}

This study uses qualitative methods to gain a deep understanding of the social changes of the people of Banda Aceh City after the tsunami. In line with the aforementioned purpose, Creswell (2010: 4) argues that qualitative research is "methods for exploring and understanding meanings by a number of individuals or groups of people ascribed to social or humanitarian problems". Denzim and Lincoln (2009) states that qualitative research is "research that uses natural settings, with the intention of interpreting phenomena that occur and are carried out by involving various existing methods". The informants were determined by purposive sampling, where the speakers were selected people who were experienced and had lived in Banda Aceh City for a long time.

Data was collected through observation and in-depth interviews with various sources, then data analysis in qualitative research was more focused during the process in the field together with data collection. Herdiansyah (2010: 158) states, "data analysis is the middle stage of a series of stages in a study that has a very important function. The results of the research produced must go through a data analysis process beforehand so that it can be accounted for, a researcher must be able to analyze the data appropriately and according to the specified procedure ".

The validity of the data is done in three ways by referring to the opinion of Moleong (2014) through:

1. Perseverance Observation.

2. Data triangulation.

3. Discussion with colleagues.

\section{Discussion}

This research was conducted to examine the social changes of the people of Banda Aceh City after the tsunami. The results showed that after the tsunami there had been a social change in the people of Banda Aceh City, there were positive changes, some were negative. The positive changes experienced by the people of Banda Aceh because they felt that many helped so that they could easily fulfill various needs in the short term, especially basic needs. With so many and easy to receive assistance at that time so that people feel comfortable, but 
behind that it turns out to give birth to a dependence on the community of Banda Aceh City for various assistance received from various parties. Whereas the greater negative impact, especially regarding social values such as the level of community participation in Banda Aceh in the development and implementation of various activities at the village level has declined, this can be seen from the waning of mutual cooperation culture inherent in community members and weak social responsibility caused by dependence and individualistic attitude.

The community of Banda Aceh was previously known as a participatory and active society but along with social change, people became reluctant to carry out various voluntary activities that were together and everything was calculated with income as obtained after the tsunami through a program (cash for work) paid by various NGOs that assist Aceh's rehabilitation program post-tsunami. With the social changes that occur so that the community is not increasingly independent, increasingly lazy while expecting various assistances to come. The social change of the people of Banda Aceh City is the values that have been built since the formation of the community structure in Banda Aceh City. There are several indicators of social change in the community of Banda Aceh after the tsunami, such as community attitudes, values, ethics, participation, interaction, customs, cooperation, relations between community groups, support (support) that has occurred.

Before the tsunami, the people of Banda Aceh were very concerned or sympathetic to others in community life. Sympathy is not only the meaning of pity, but far from that sympathy also speaks of the desire to do and help caused by a sense of interest in doing so. However, after the tsunami anti-social behavior emerged as a result of social change. Concerning the antisocial behavior in the community of Banda Aceh City can be seen from the attitude of individualism as a form of shifting values in society.

\section{Conclusion}

Based on the discussion as outlined above, it can be concluded that after the tsunami there has been a social change in the people of Banda Aceh, the changes other than those that are positive are also negative. Positive changes in the community feel that many help so that they can meet their needs in the short term, while the larger negative impacts, especially regarding social values such as the level of community participation in Banda Aceh in the construction of village gampers, are evident from the fading of mutual cooperation inherent in community members and weak social responsibility resulting from dependence and individualistic attitudes. However, on the other hand, after the tsunami, the people of Banda Aceh were more open, the openness of the people of Banda Aceh had positive and negative impacts on the lives of these people. The social changes seen from the lifestyle of the people have shifted towards the modern direction and have begun to abandon various traditions such as participation in mutual cooperation activities and waning the values of cooperation which have led to various anti-social behaviors as a form of social change in community life in Banda Aceh.

\section{References}

Bachtiar, Wardi. (2006). Sosiologi Klasik dari Camte Hingga Parsons. Bandung: Remaja Rosadakarya.

Creswell, John. W. (2010). Research Design. Yogyakarta: Pustaka Pelajar.

David, Berry. (2003).The Principles of sociology. Jakarta: PT. Raja Grafindo Persada. 
Dewi, Wualansari. (2008). Sosiologi. Konsep dan Teori. Bandung: PT Refika Aditama.

George, Ritzer Douglas J. Goodman. (2014). Teori Sosiologi. Bantul: Kreasi Wacana.

Moleong, Lexy J. (2014). Metode Penelitian Kualitatif. Bandung: Remaja Rosdakarya.

Ngarawula, Bonaventura. (2012). Memahami Nasionalisme Masyarakat Lokal. Perspektif Sosiologi. Malang: Universitas Negeri Malang.

Salim, Agus (2012). Perubahan Sosial. Sketsa Teori dan Repleksi Metodologi Kasus Indonesia. Yokyakarta: Tiara wacana.

Soekanto, Soerjono. (2012). Sosiologi Suatu Pengantar. Jakarta: Raja Grafindo Persada.

Sukidin, dkk. (2003). Pengantar Ilmu Budaya, Surabay: Insan Cendikia.

Sukowati, Praptining. (2011). Perubahan Sosial \& Kebijakan Pembangunan Berwawasan Lingkungan. Malang: Bayumedia Publishing Anggota IKAPI. 